\title{
EDUCORETAX
}

Volume 1 No. 4, Desember 2021

\section{ANALISIS KEGIATAN PENILAIAN UNTUK PENGGALIAN POTENSI PAJAK: STUDI KASUS KANTOR WILAYAH DJP JTD}

\author{
Deshita Maharani Raharjo $^{1)}$ dan Arif Nugrahanto ${ }^{2)}$ \\ 1) deshita.raharjo@gmail.com, Politeknik Keuangan Negara STAN \\ 2) arifn@pknstan.ac.id, Politeknik Keuangan Negara STAN* \\ *email korespondensi
}

\begin{abstract}
DGT has implemented various strategies to increase tax revenue. One of these efforts is through optimization the valuation role in analising and identification of tax potential. By using a qualitative approach through library research and field research, in the form of direct field observations and interviews, this research tries to identify the extent to which the optimization of valuation activities as an effort to fulfil tax revenue. Based on the analysis, we concludes that the optimization of the valuation activities at the Regional Office of the DJP has only been carried out in any certain stages, thare are supervision activities, audit activities, and tax collection. Meanwhile, in the extensification activities and investigation activities, valuation has not yet involved. Furthermore, we also identifies several challenges faced in optimizing the valuation, there are the limited access to taxpayer data, the limited number of appraisers, and the reluctance in involving appraisers in the strategy.
\end{abstract}

Keywords : Tax effort, tax potential, valuation, supervision, audit

\begin{abstract}
Abstrak
Berbagai strategi dilakukan oleh DJP untuk meningkatkan penerimaan pajak. Salah satunya dalam bentuk strategi penggalian potensi pajak melalui kegiatan penilaian yang dituangkan dalam Surat Edaran Direktur Jenderal Pajak tentang Optimalisasi Penilaian (Appraisal) untuk Penggalian Potensi Pajak dan Tujuan Perpajakan Lainnya. Dengan menggunakan pendekatan kualitatif melalui studi kepustakaan dan penelitian lapangan, Penelitian ini bertujuan mengidentifikasi sejauh mana pelaksanaan kegiatan optimalisasi penilaian sebagai upaya untuk mengamankan target penerimaan pajak dilaksanakan. Berdasarkan analisis, kesimpulan yang diperoleh antara lain bahwa pelaksanaan optimalisasi penilaian dalam rangka penggalian potensi pajak di Kanwil DJP JTD baru dilaksanakan untuk tahap kegiatan pengawasan, kegiatan pemeriksaan, dan penagihan pajak. Sedangkan kegiatan ekstensifikasi dan penyidikan masih belum pernah dilakukan pelibatan Penilai di dalamnya. Lebih lanjut, Penulis juga mengidentifikasi beberapa tantangan yang dihadapi dalam optimalisasi penilaian, yaitu adanya keterbatasan akses data wajib pajak, adanya keterbatasan jumlah Penilai, dan masih adanya keengganan pelibatan penilai dalam kegiatan penggalian potensi pajak.
\end{abstract}

Kata Kunci : penggalian potensi, potensi pajak, penilaian, pengawasan, pemeriksaan

\section{PENDAHULUAN}

Pemungutan pajak di Indonesia menganut sistem self assessment. Dalam sistem self assessment kegiatan menghitung, membayar, dan melaporkan pajak yang terutang dilakukan sepenuhnya oleh wajib pajak sesuai ketentuan peraturan perundang-undangan perpajakan. berdasarkan sistem ini, wajib pajak dituntut untuk aktif dalam memenuhi seluruh kewajiban perpajakannya. Dalam beberapa penelitian menyebutkan bahwa sistem self assessment yang dijalankan pemerintah hingga saat ini belum maksimal. Keberhasilan sistem self assessment ini tidak dapat tercapai tanpa kesadaran dan kejujuran dari masyarakat khususnya wajib pajak untuk melaksanakan kewajiban perpajakan sesuai dengan ketentuan yang berlaku (Akbar, Atmanto dan Jauhari, 2015).

Kurangnya kesadaran wajib pajak membuat tax ratio Indonesia bergerak stagnan selama beberapa tahun terakhir. Dalam laporan Revenue Statistics in Asian and Pacific Economies 2019 yang dipublikasikan oleh Organisation for Economic Co-operation and Development (OECD), tax ratio Indonesia hanya sebesar 11,5\%. Dengan angka tersebut dapat dikatakan bahwa tax ratio Indonesia tertinggal jauh dari rata-rata tax ratio OECD yang mencapai $34,2 \%$. Lebih lanjut, data Laporan Kinerja Direktorat Jenderal Pajak (LAKIN DJP) tahun 2019 menunjukkan pengaruh langsung kurangnya kesadaran wajib pajak terhadap penerimaan pajak. 


\section{EDUCORETAX}

Volume 1 No. 4, Desember 2021

Berbagai strategi dilakukan oleh DJP untuk meningkatkan kepatuhan pajak. Upaya tersebut salah satunya dalam bentuk strategi peningkatan kepatuhan pajak melalui kegiatan penilaian yang dituangkan dalam Surat Edaran Direktur Jenderal Pajak Nomor SE-61/PJ/2015 tentang Optimalisasi Penilaian (Appraisal) untuk Penggalian Potensi Pajak dan Tujuan Perpajakan Lainnya. Surat edaran ini menegaskan bahwa kegiatan penilaian dapat dioptimalkan untuk mendukung penggalian potensi pajak, serta memberikan pedoman mengenai langkahlangkah untuk menggali potensi pajak, khususnya Pajak Bumi dan Bangunan (PBB), Pajak Penghasilan (PPh) atau Pajak Pertambahan Nilai (PPN), dan tujuan perpajakan lainnya, seperti penagihan pajak.

Berdasarkan hal-hal di atas, penelitian ini bertujuan untuk mengkaji sejauh mana pelaksanaan kegiatan optimalisasi penilaian sebagai upaya untuk mengamankan target penerimaan pajak, khususnya pada Kanwil DJP serta mengidentifikasi tantangan-tantangan yang muncul dalam kegiatan optimalisasi penilaian tersebut.

\section{KAJIAN PUSTAKA \\ Pengertian Penilaian}

Definisi penilaian menurut Konsep dan Prinsip Umum Penilaian (KPUP) butir 4.5 dalam Standar Penilaian Indonesia (SPI) 2018 adalah proses pekerjaan seorang penilai dalam memberikan opini tertulis mengenai nilai ekonomi pada saat tertentu. Kata "Penilaian" digunakan untuk mengacu kepada proses penyusunan estimasi nilai dan dapat juga mengacu pada kesimpulan penilaian. Sedangkan menurut SE-54/PJ/2016, Penilaian adalah serangkaian kegiatan untuk menentukan besaran suatu jenis nilai tertentu pada suatu saat tertentu yang dilaksanakan secara objektif dan profesional berdasarkan suatu standar penilaian dalam rangka melaksanakan ketentuan peraturan perundang-undangan perpajakan.

Berdasarkan definisi di atas, dalam penelitian ini penilaian adalah serangkaian kegiatan yang dilaksanakan oleh penilai untuk menentukan besaran suatu jenis nilai pada saat tertentu dalam rangka melaksanakan ketentuan perundang-undangan perpajakan.

Menurut Darwin (2011:11), penting bagi penilai untuk mengetahui tujuan dilaksanakannya suatu penilaian karena hal ini berpengaruh terhadap jenis nilai dan pendekatan yang akan digunakan. Darwin mengemukakan delapan tujuan penilaian secara umum, antara lain penilaian dalam rangka penentuan nilai pasar terbuka (open market value), penilaian untuk tujuan penjualan properti (kepentingan penjual), penilaian untuk tujuan pembelian properti (kepentingan pembeli), penilaian untuk keperluan agunan ke lembaga keuangan, penilaian untuk keperluan asuransi atas harta tetap, Penilaian untuk keperluan penggabungan usaha, penilaian untuk keperluan go public perusahaan, dan penilaian untuk keperluan perpajakan. Dalam penelitian ini, penilaian yang dianalisis lebih lanjut adalah penilaian untuk tujuan yang sifatnya spesifik, yaitu tujuan perpajakan.

Lebih lanjut, dalam Surat Edaran Direktur Jenderal Pajak Nomor SE-54/PJ/2016 (selanjutnya disebut SE-54/PJ/2016) dijelaskan bahwa penilaian bertujuan untuk menentukan besaran suatu jenis nilai tertentu atas objek penilaian berupa properti, bisnis, atau aset tak berwujud, yang dapat digunakan sebagai dasar untuk menghitung pajak terutang atau tujuan lain dalam rangka melaksanakan fungsi pengawasan, pemeriksaan, penyidikan, penagihan, dan fungsi lainnya sesuai ketentuan peraturan perundang-undangan perpajakan.

Kegiatan penilaian sangat erat kaitannya dengan keberadaan objek penilaian. Sehubungan dengan hal itu, Darwin (2011:2) dalam buku Teori Dasar Penilaian memberi penjelasan bahwa objek penilaian adalah segala sesuatu yang dimiliki oleh seseorang berupa harta, baik harta berwujud maupun tidak berwujud. Atas harta yang dimiliki tersebut selanjutnya disebut sebagai properti. Properti yang merupakan harta kekayaan seseorang yang dapat diklasifikasikan sebagai properti berwujud (properti berwujud dan bergerak, properti 


\section{EDUCORETAX}

Volume 1 No. 4, Desember 2021

berwujud tidak bergerak dan efek) dan properti tidak berwujud, yaitu properti yang tidak dapat dilihat secara nyata namun keberadaannya diakui, seperti hak cipta, hak paten, dan lain-lain.

\section{Optimalisasi Penilaian untuk Penggalian Potensi Pajak}

Dalam rangka memenuhi target penerimaan pajak, Direktorat Jenderal Pajak (selanjutnya disebut DJP) melakukan berbagai strategi. Salah satunya melalui optimalisasi penilaian untuk penggalian potensi pajak dan tujuan perpajakan lainnya. Strategi ini dituangkan dalam bentuk surat edaran Direktur Jenderal Pajak. Dalam enam (6) tahun terakhir, terdapat dua (2) surat edaran yang menjadi pedoman pelaksanaan penggalian potensi pajak melalui kegiatan penilaian. Berikut ini ringkasan pedoman pelaksanaan kegiatan tersebut.

1. Surat Edaran Dirjen Pajak Nomor SE-61/PJ/2015 tentang Optimalisasi Penilaian (Appraisal) untuk Penggalian Potensi Pajak dan Tujuan Perpajakan Lainnya. Latar belakang munculnya SE ini adalah sebagai salah satu upaya upaya pengamanan target penerimaan pajak. Surat edaran ini memberikan penjelasan dan panduan bahwa penilaian dapat dioptimalkan untuk menunjang kegiatan penggalian potensi pajak yang meliputi kegiatan ekstensifikasi, pengawasan, pemeriksaan, penyidikan, dan tujuan perpajakan lainnya seperti penagihan. Optimalisasi yang dimaksud adalah untuk menggali potensi pajak yaitu tidak hanya Pajak Bumi dan Bangunan (PBB) namun juga Pajak Pertambahan Nilai (PPN), serta Pajak Penghasilan (PPh). Berdasarkan SE61/PJ/2015, Penilaian dapat dilakukan dalam hal:

a) Terdapat peristiwa atau transaksi tanpa pembayaran yang mengandung perubahan nilai atas suatu objek dan Wajib Pajak dalam hal ini diwajibkan untuk menggunakan nilai pasar dalam pelaporannya. Contoh: revaluasi aktiva tetap, pengalihan harta dalam penyertaan modal, pengalihan harta dalam hal terjadi aksi korporasi, Kegiatan Membangun Sendiri (KMS), transaksi tukar menukar harta, waris, hibah.

b) Terdapat transaksi yang diikuti dengan pembayaran dan harga dalam transaksi tersebut dapat dinilai kewajarannya berdasarkan data pembanding yang tersedia secara luas. Contoh: Transaksi jual beli atau pengalihan hak atas tanah dan bangunan, penjualan aktiva bekas yang merupakan Barang Kena Pajak (BKP), sewa gedung, dan sejenisnya.

c) Terdapat biaya yang terkait dengan penggunaan aktiva perusahaan. Contoh: biaya amortisasi, biaya penyusutan (depresiasi), atau cadangan piutang tak tertagih.

2. Surat Edaran Dirjen Pajak Nomor SE/05/PJ/2020 tentang Prosedur Pelaksanaan Penilaian untuk Tujuan Perpajakan. Ketentuan mengenai penilaian untuk tujuan perpajakan terus diperbarui dan disempurnakan dengan tujuan untuk mengoptimalkan pelaksanaan penilaian. Berlakunya SE/05/PJ/2020 pada 27 Februari 2020 sekaligus menandai bahwa SE/61/PJ/2020 dinyatakan sudah tidak berlaku lagi. Penyempurnaan prosedur penilaian dalam surat edaran ini diantaranya adanya penambahan fitur baru, berupa penilaian proaktif yang didasarkan pada Daftar Sasaran Prioritas Penilaian (DSPPn). Tujuan penilaian proaktif ini adalah untuk memberikan lebih banyak data (tyang terkait dengan potensi pajak) kepada Account Representative (fungsi pengawasan) dan/atau Pemeriksa Pajak (fungsi pemeriksaan) atau fungsi terkait lainnya dalam rangka penggalian potensi pajak. Sebelumnya, sebagian besar kegiatan penilaian hanya dilakukan setelah adanya Surat Permintaan Bantuan Penilai.

Lebih lanjut, berdasarkan SE-05/PJ/2020, Penilaian dapat dilakukan dalam hal:

a) Terdapat transaksi yang menurut ketentuan peraturan perundang-undangan perpajakan diharuskan untuk menggunakan Jumlah yang seharusnya dikeluarkan atau diterima (dalam hal jual beli harta yang terindikasi hubungan 


\section{EDUCORETAX}

Volume 1 No. 4, Desember 2021

istimewa), Harga pasar (dalam hal tukar menukar harta, dan/atau perolehan atau pengalihan harta dalam rangka aksi), Nilai pasar (dalam hal pengalihan harta hibah atau pengalihan harta yang diterima oleh badan sebagai pengganti saham atau penyertaan modal), Harga pasar wajar (dalam hal penyerahan Barang Kena Pajak atau Jasa Kena Pajak yang dipengaruhi hubungan istimewa), Harga limit, atau Nilai hasil penilaian yang dilakukan oleh DJP (dalam hal penghitungan nilai harta bersih selain kas dalam rangka pelaksanaan Undang-Undang Pengampunan Pajak).

b) Terdapat data lain yang mengindikasikan ketidakwajaran nilai yang dilaporkan oleh Wajib Pajak, antara lain:

1. Indikasi ketidakwajaran atas harga perolehan atau nilai sisa buku harta berwujud yang mempengaruhi besarnya biaya penyusutan.

2. Indikasi ketidakwajaran atas harga perolehan atau nilai sisa buku harta tidak berwujud yang mempengaruhi besarnya biaya amortisasi.

3. Indikasi ketidakwajaran penghasilan dari transaksi pengalihan harta atas tanah dan/atau bangunan, usaha jasa konstruksi, usaha real estate, dan persewaan tanah dan/atau bangunan yang dikenakan $\mathrm{PPh}$ final Pasal 4 ayat (2) huruf d UU PPh.

c) Terdapat objek Pajak Bumi dan Bangunan Sektor Perhutanan, Perkebunan, Pertambangan dan sektor lainnya yang memerlukan penilaian lapangan.

\section{METODE}

Metode penelitian yang digunakan dalam penelitian ini adalah penelitian kualitatif. Penulis menggunakan pendekatan studi kepustakaan dan penelitian lapangan, dalam bentuk observasi langsung di lapangan dan wawancara, untuk mengakumulasi data penelitian.

Dalam melakukan studi kepustakaan, penulis mengumpulkan seluruh dokumentasi berupa ketentuan-ketentuan perpajakan yang terkait dengan kegiatan penilaian dan kegiatan optimalisasi penilaian dalam rangka penggalian potensi perpajakan. Berdasarkan studi ini, paling tidak terdapat sembilan dokumen, berupa surat edaran Direktur Jenderal Pajak, yang terkait dengan pelaksanaan penilaian dan penggalian potensi perpajakan. Salah satunya yang paling substansial adalah Surat Edaran Direktur Jenderal Pajak Nomor SE-61/PJ/2015 tentang Optimalisasi Penilaian (Appraisal) Dalam Rangka Penggalian Potensi Pajak Maupun untuk Tujuan Perpajakan Lainnya.

Pelaksanaan studi lapangan dilakukan dengan melakukan observasi langsung di Kantor Wilayah Direktorat Jenderal Pajak JTD (selanjutnya disebut Kanwil DJP JTD) pada tanggal 10 Februari 2020 - 3 April 2020. Pemilihan Kanwil DJP JTD sebagai objek penelitian berdasarkan pertimbangan biaya mengingat lokasinya paling dekat dengan domisili Penulis.

Selama proses observasi, Penulis melakukan wawancara dengan pihak-pihak yang terkait, antara lain fungsional penilai, yang merupakan pelaku utama dalam kegiatan penilaian, Kepala Seksi Bimbingan Pengenaan, Pendaftaran, dan Penilaian, dan Kepala Bidang Pendaftaran, Ekstensifikasi, dan Penilaian di Kanwil DJP JTD. Wawancara dilaksanakan secara semi-terstruktur dengan memberikan gambaran pertanyaan-pertanyaan umum minimal satu hari sebelum wawancara dilaksanakan, bertempat di kantor narasumber yang bersangkutan.

\section{HASIL DAN PEMBAHASAN}

\section{Kegiatan Penilaian untuk Penggalian Potensi Pajak}

Kegiatan optimalisasi penilaian di Kanwil DJP JTD dilaksanakan dengan mengacu pada ketentuan yang ada, yaitu SE-61/PJ/2015 dan SE-05/PJ/2020. Berdasarkan hasil wawancara dengan Kepala Bidang Pendaftaran, Ekstensifikasi, dan Penilaian, Kepala Seksi Bimbingan 


\section{EDUCORETAX}

Volume 1 No. 4, Desember 2021

Pengenaan, Pendaftaran, dan Penilaian, serta Fungsional Penilai Pajak di Kanwil DJP JTD, pelaksanaan optimalisasi penilaian dapat diuraikan sebagai berikut:

1. Penilaian dalam Kegiatan Ekstensifikasi

Proses ekstensifikasi diawali dengan analisis data internal ataupun eksternal yang dimiliki dan/atau diperoleh untuk mengetahui ada atau tidaknya transaksi atau peristiwa yang dilakukan oleh wajib pajak. Seksi Ekstensifikasi dan Penyuluhan bekerja sama dengan penilai untuk menentukan ada atau tidaknya indikasi bahwa nilai atau harga transaksi tersebut tidak sesuai dengan keadaan yang sebenarnya yang menyebabkan tidak terpenuhinya syarat objektif dan subjektif sebagai wajib pajak. Apabila terdapat indikasi nilai atau harga transaksi yang tidak sesuai dengan keadaan yang sebenarnya, maka wajib pajak yang bersangkutan akan dimasukkan ke dalam Daftar Sasaran Ekstensifikasi (DSE).

Pelaksanaan kegiatan ekstensifikasi seringkali dilakukan dengan cara survei secara langsung di lapangan. Hal tersebut salah satunya bertujuan untuk mendata para pelaku usaha yang belum memiliki NPWP. Setelah ditemukan WP yang selama ini belum terdaftar, penilai dilibatkan untuk menilai kewajaran omset dari WP yang bersangkutan.

Laporan penilaian selanjutnya disampaikan kepada Pelaksana/Account Representative Seksi Ekstensifikasi dan Penyuluhan untuk menjadi bahan pertimbangan pemberian NPWP sekaligus dilakukan pengawasan terhadap kewajiban perpajakan WP dengan mempertimbangkan analisis kewajaran yang disampaikan oleh penilai.

Sepanjang tahun 2018 sampai dengan tahun 2019, tidak ada kegiatan penilaian dalam rangka ekstensifikasi yang dilakukan oleh Penilai Kanwil DJP JTD. Penilaian yang dilakukan lebih banyak mengarah ke kegiatan pengawasan.

2. Penilaian dalam Kegiatan Pengawasan

Penilaian dalam kegiatan pengawasan dilaksanakan apabila terdapat permintaan Account Representative supaya melakukan kegiatan penilaian atas wajib pajak yang berada dalam pengawasannya. Berdasarkan data penilaian di Kanwil DJP JTD, penilaian dalam rangka pengawasan pada tahun 2018 berhasil mengidentifikasi potensi pajak sebesar Rp2,6 trilyun dengan jumlah kasus sebanyak 13 wajib pajak.

Tahun selanjutnya (2019), potensi pajak yang berhasil diidentifikasi oleh penilai meningkat menjadi Rp3,9 trilyun dengan jumlah kasus yang jauh lebih sedikit, yaitu sembilan kasus. Hal ini berarti terjadi peningkatan kinerja sebesar 50\% dibandingkan tahun sebelumnya. Situasi ini mengindikasikan bahwa kegiatan penilaian yang dilakukan oleh Penilai di Kanwil DJP JTD menjadi jauh lebih efektif. Selain itu, situasi tersebut bisa jadi juga disebabkan banyaknya WP yang tidak melaporkan data nilai objek pada tahun 2019.

3. Penilaian dalam Kegiatan Pemeriksaan

Tenaga ahli dapat dilibatkan untuk mendukung kegiatan pemeriksaan. Dalam hal Tim Pemeriksa KPP/Kanwil/ Kantor Pusat membutuhkan bantuan penilaian, Tim Pemeriksa tersebut dapat menerbitkan Nota Dinas Permintaan Bantuan Penilai atau Surat Permintaan Bantuan Penilai. Nota Dinas Permintaan Bantuan Penilai disampaikan apabila terdapat Fungsional Penilai Pajak di unit kerja Tim Pemeriksa tersebut. Sedangkan Surat Permintaan Bantuan Penilai disampaikan ke unit kerja lain dalam satu wilayah kanwil atau ke unit kerja lain yang lebih tinggi dikarenakan tidak adanya penilai atau kekurangan tenaga penilai di unit kerja Tim Pemeriksa tersebut.

Kegiatan penilaian dalam rangka pemeriksaan yang ditangani oleh Penilai Kanwil DJP JTD selama tahun 2018 terdapat 13 kasus yang keseluruhan objeknya adalah terkait pengalihan hak atas tanah dan bangunan yang terkait dengan hubungan 


\section{EDUCORETAX}

Volume 1 No. 4, Desember 2021

istimewa. Sesuai dengan Pasal 18 Ayat (3) UU PPh, Menteri Keuangan berwenang untuk menentukan kembali besarnya penghasilan bagi wajib pajak yang memiliki hubungan istimewa sesuai ketentuan perundang-undangan yang berlaku. Dalam kasus ini, penilai membantu tim pemeriksa untuk menentukan kewajaran nilai dari transaksi tersebut dan berhasil mengidentifikasi potensi pajak sebesar Rp1,5 trilyun pada tahun 2018.

Kegiatan Pemeriksaan yang melibatkan penilai pada tahun 2019 mengalami penurunan kuantitas. Terdapat lima kasus yang terdiri dari empat kasus penilaian terkait Pasal 4 Ayat (2) UU PPh dan satu penilaian terkait pengalihan saham yang terindikasi hubungan istimewa. Penurunan jumlah kasus penilaian ternyata diikuti dengan menurunnya kontribusi penerimaan pajak, menjadi hanya sekitar Rp15,1 milyar.

4. Penilaian dalam Kegiatan Penyidikan

Dalam praktiknya di Kanwil DJP JTD, sepanjang tahun 2018-2019 tidak terdapat kegiatan penilaian dalam kegiatan penyidikan. Berdasarkan wawancara dnegan Lukman (Fungsional Penilai) bahwa sepanjang tahun 2018-2019, tidak ada permintaan bantuan dari penyidik untuk membantu penilaian dalam penyidikan. Hal ini kemungkinan disebabkan karena jumlah kasus penyidikan di Kanwil DJP JTD masih dapat ditangani dengan sumber daya penyidik yang ada.

5. Penilaian dalam Kegiatan Penagihan

Penilai dapat dilibatkan dalam kegiatan penagihan pajak, yaitu untuk keperluan penentuan nilai objek sita sesuai dengan Pasal 12 UU Penagihan Pajak dengan Surat Paksa dan penentuan nilai limit lelang sesuai dengan Pasal 36 Peraturan Menteri Keuangan Nomor 93/PMK.06/2020 tentang Petunjuk Pelaksanaan Lelang.

Sepanjang tahun 2018-2019, tidak terdapat kegiatan penilaian dalam rangka penagihan di Kanwil DJP JTD. Namun pada tahun sebelumnya, berdasarkan wawancara dengan Penilai, kegiatan penilaian pernah dilaksanakan dalam rangka penagihan pajak. Penilaian tersebut yaitu bertujuan untuk menentukan nilai limit lelang kendaraan bermotor roda empat. Lelang dilakukan terhadap barang sitaan pajak. Barang sitaan yang tidak dapat dilelang adalah barang yang berupa obligasi, deposito, uang tunai, saham, ataupun surat berharga lainnya.

\section{Kontribusi Kegiatan Penilaian}

Berdasarkan data perbandingan sebagaimana disajikan pada tabel di bawah ini, pada tahun 2018 dan 2019 kegiatan penilaian memberikan kontribusi masing-masing sebesar 0,29\% dan 0,17\% dari total penerimaan Kanwil DJP JTD. Realisasi penerimaan pada tahun 2019 dari penilaian mengalami penurunan $0,12 \%$ dari tahun sebelumnya. Penurunan ini disebabkan karena menurunnya jumlah kegiatan penilaian yang dilibatkan dalam kegiatan penggalian potensi pajak.

Tabel Kontribusi Kegiatan Penilaian Terhadap Penerimaan Pajak Kanwil DJP JTD

\begin{tabular}{|c|c|c|c|}
\hline Tahun & Realisasi Penerimaan Kanwil & Realisasi Penilaian & Persentase (\%) \\
\hline 2018 & Rp11.423.926.918.840 & Rp33.621.110.735 & 0,29 \\
\hline 2019 & Rp12.663.807.992.406 & Rp21.679.872.158 & 0,17 \\
\hline
\end{tabular}

Sumber: diolah oleh penulis

Meskipun nilai realisasi penilaian terhadap penerimaan pajak mengalami penurunan, namun apabila dilihat dari kontribusi per kasus pemeriksaan, maka nilai realisasi penilaian ini mengalami kenaikan dari sebesar Rp2,5 trilyun per kasus (2018) menjadi Rp4,3 trilyun per kasus penilaian pada 2019. Adanya penaikan ini mengindikasikan bahwa kegiatan penilaian yang dilaksanakan untuk mendukug kegiatan pemeriksaan makin berjalan dengan efektif. 


\section{EDUCORETAX}

Volume 1 No. 4, Desember 2021

\section{Tantangan Pelaksanaan Optimalisasi Penilaian}

Dalam melaksanakan Optimalisasi Penilaian (Appraisal) untuk Penggalian Potensi Pajak dan Tujuan Perpajakan Lainnya (SE-61/PJ/2015 dan SE/05/PJ/2020), terdapat beberapa tantangan yang dihadapi oleh Kanwil DJP JTD. Berikut analisis tantangan-tantangan yang dihadapi dalam pelaksanaan optimaliasasi penilaian.

Keterbatasan Akses Data Wajib Pajak. Dalam melakukan penilaian, penilai membutuhkan data-data wajib pajak terkait objek penilaian. Berdasarkan wawancara dengan Lukman, bahwa seringkali penilai sulit untuk mendapatkan data-data yang dibutuhkan sehingga harus mengajukan permohonan permintaan data ke berbagai pihak (Kantor Pusat DJP, Bank, dsb.). Meskipun terdapat beberapa aplikasi yang dimiliki oleh DJP, namun Penilai masih menemui kesulitan dalam mengakses data. Salah satunya adalah Approweb (Aplikasi Profil Berbasis Web) yang hanya bisa diakses oleh Account Representative, Kepala Seksi, dan Pemeriksa. Penilai tidak memiliki akses terhadap data WP dalam aplikasi tersebut, sehingga apabila penilai membutuhkan data WP maka penilai harus meminta data ke pihak yang memiliki akses terhadap data tersebut.

Keterbatasan SDM Penilai. Jumlah penilai di seluruh unit kerja Kanwil DJP JTD masih belum ideal. Bahkan ada 4 unit kantor pajak yang tidak terdapat penilai. Hal ini mengurangi efisiensi kegiatan penggalian potensi pajak di unit kantor pajak yang bersangkutan. Umumnya, satu kasus penilaian diselesaikan dalam jangka waktu 1-2 bulan, sehingga dalam satu tahunnya rata-rata seorang penilai maksimal dapat menyelesaikan 6-10 kegiatan penilaian. Berdasarkan wawancara dengan Kepala Bidang Pendaftaran, Ekstensifikasi, dan Penilaian, bahwa bahwa idealnya di tiap-tiap unit kantor pajak harus memiliki dua sampai tiga orang penilai agar bisa menghasilkan penilaian yang lebih banyak sehingga mampu mengidentigfikasi potensi pajak yang lebih besar.

Keengganan Pimpinan untuk Melibatkan Penilai. Berdasarkan wawancara dengan Lukman, bahwa sering ditemui pimpinan di suatu unit kantor pajak merasa tidak perlu untuk melibatkan penilai dalam suatu kegiatan penggalian potensi pajak. Misalnya dalam kegiatan pemeriksaan terhadap wajib pajak yang terindikasi hubungan istimewa, pimpinan enggan melibatkan penilai untuk menentukan kewajaran nilainya. Meskipun keengganan tersebut bersifat subjektif, namun nampaknya ketentuan yang memuat pelaksanaan kegiatan penilaian dalam rangka penggalian potensi pajak dalam bentuk surat edaran, tidak memiliki daya ikat yang kuat.

\section{PENUTUP}

Pelaksanaan optimalisasi penilaian dalam rangka penggalian potensi pajak di Kanwil DJP JTD sebagaimana diatur dalam SE-61/PJ/2015 dan SE-05/PJ/2020 baru dilaksanakan pada tahap kegiatan pengawasan, kegiatan pemeriksaan, dan penagihan pajak. Masih terdapat beberapa kegiatan penggalian potensi pajak yang belum penilaian, antara lain kegiatan ekstensifikasi dan penyidikan. Meskipun begitu, kontribusi penerimaan yang dihasilkan dari kegiatan penilaian ini cukup signifikan dan mengalami peningkatan dari Rp2,5 trilyun per kasus (2018) menjadi Rp4,3 trilyun per kasus (2019).

Terkait dengan tantangan yang dihadapi dalam pelaksanaan ketentuan tentang optimalisasi penilaian dalam rangka penggalian potensi pajak, terdapat tiga tantangan, yaitu masih ditemukannya keterbatasan akses data wajib pajak yang dialami oleh Penilai, adanya keterbatasan jumlah Penilai pada unit kantor pajak, dan masih adanya keengganan untuk menggunakan kegiatan penilaian sebagai salah satu instrument optimalisasi penggalian potensi pajak 


\section{EDUCORETAX}

Volume 1 No. 4, Desember 2021

\section{DAFTAR PUSTAKA}

Asmarani, Nora Galuh Candra. 2020. Prosedur Penilaian Objek Pajak di KPP Bagian 1 dan 2. (https://news.ddtc.co.id/ini-perincian-prosedur-penilaian-objek-pajak-di-kpp-bag1-19525?page_y=0). Diakses pada tanggal 18 Mei 2020.

Darwin. 2011. Teori Dasar Penilaian. Jakarta: Sekolah Tinggi Akuntansi Negara.

Diamastuti, Erlina. 2016. "Ke(Tidak)Patuhan Wajib Pajak: Potret Self Assessment System". Dalam Ekuitas: Jurnal Ekonomi dan Keuangan Vol. 20 No. 3, September, hlm. 281. Jakarta.

Hidayati, Wahyu dan Budi Harjanto. 2001. Konsep Dasar Penilaian Properti. Yogyakarta: BPFE Yogyakarta.

Judowinarso, Endarto. 2011. Teori Dasar Penilaian. Jakarta: Sekolah Tinggi Akuntansi Negara.

Kantor Wilayah DJP Jawa Tengah II. 2019. Buku Profil Kantor Wilayah DJP Jawa Tengah II Tahun 2019. Surakarta: Kantor Wilayah DJP Jawa Tengah II.

Littleduck. 2015. Ditjen Pajak Keluarkan Aturan Menggali Data Wajib Pajak. (https://pemeriksaanpajak.com/2015/09/28/ditjen-pajak-keluarkan-aturanmenggali-data-wajib-pajak/). Diakses pada tanggal 18 April 2020.

MAPPI. 2018. Kode Etik Penilai Indonesia dan Standar Penilaian Indonesia Edisi VIII. 2018. Jakarta: MAPPI.

Muliawati, Nela Gustina. 2019. Kompleksitas Pajak: Tax Ratio, Perekonoman, dan Kesadaran Pajak. (https://www.pajak.go.id/id/artikel/kompleksitas-pajak-tax-ratioperekonomian-dan-kesadaran-pajak). Diakses pada tanggal 2 April 2020.

Ortax. 2016. Optimalisasi Pemanfaatan Penilaian (Appraisal) Dalam Rangka Penggalian Potensi Pajak. (https://www.ortax.org/ortax/?modnfo\&page=show\&id=128\&list=1). Diakses pada tanggal 14 Mei 2020.

Tim Pajakku. 2019. Wajib Pajak Non Efektif. (https://www.pajakku.com/forumtopic/5e04151ad7a79b73fea95cec/Wajib-Pajak-Non-Efektif-(NE)). Diakses pada tanggal 18 Mei 2020.

Tim Penilaian Property Indonesia. 2019. Jenis-jenis Nilai. (http://penilaianproperty.blogspot.com/2009/04/jenis-jenis-nilai.html). Diakses pada tanggal 30 Mei 2020.

Yonimurwanto Nugroho, Hanik Susilowati. 2018. "Penilaian Dalam Rangka Lelang Barang Sitaan Pajak”. Dalam Jurnal Seminar Nasional I Universitas Pamulang. Banten.

Zulfina, Susi. 2015. Pengantar Hukum Pajak. Jakarta: Sekolah Tinggi Akuntansi Negara.

Zulfina, Susi. 2015. Ketentuan Umum dan Tata Cara Perpajakan. Jakarta: Sekolah Tinggi Akuntansi Negara.

Direktorat Jenderal Pajak. 2019. Laporan Kinerja Direktorat Jenderal Pajak (LAKIN DJP) Tahun 2019. Jakarta: Direktorat Jenderal Pajak.

Direktorat Jenderal Pajak. 2016. Peraturan Direktur Jenderal Pajak Nomor PER-24/PJ/2016 tentang Tata Cara Penilaian untuk Penentuan Nilai Jual Objek Pajak Sebagai Dasar Pengenaan Pajak Bumi dan Bangunan.

Direktorat Jenderal Pajak. 2015. Surat Edaran Direktur Jenderal Pajak Nomor SE61/PJ/2015 tentang Optimalisasi Penilaian (Appraisal) Dalam Rangka Penggalian Potensi Pajak Maupun untuk Tujuan Perpajakan Lainnya.

Direktorat Jenderal Pajak. 2016. Surat Edaran Direktur Jenderal Pajak Nomor SE54/PJ/2016 tentang Petunjuk Teknis Pelaksanaan Kegiatan Penilaian Properti, Penilaian Bisnis, dan Penilaian Aset Tak Berwujud untuk Tujuan Perpajakan.

Direktorat Jenderal Pajak. 2017. Surat Edaran Direktur Jenderal Pajak Nomor SE18/PJ/2017 tentang Tata Cara Penunjukan Petugas Penilai Pajak. 


\section{EDUCORETAX}

Volume 1 No. 4, Desember 2021

Direktorat Jenderal Pajak. 2020. Surat Edaran Direktur Jenderal Pajak Nomor SE05/PJ/2020 tentang Prosedur Pelaksanaan Penilaian untuk Tujuan Perpajakan.

Direktorat Jenderal Pajak. 2020. Surat Edaran Direktur Jenderal Pajak Nomor SE07/PJ/2020 tentang Kebijakan Pengawasan dan Pemeriksaan.

Direktorat Jenderal Pajak. 2001. Surat Edaran Nomor SE-06/PJ.9/2001 tentang Pelaksanaan Ekstensifikasi Wajib Pajak dan Intensifikasi Pajak. Jakarta: Direktorat Jenderal Pajak.

Direktorat Jenderal Pajak. 2016. Surat Edaran Direktur Jenderal Pajak Nomor SE03/PJ/2016 tentang Petunjuk Kegiatan Ekstensifikasi, Pendaftaran, Pendataan, Penilaian, dan Kegiatan Pendukung Lainnya Tahun 2016. Jakarta: Direktorat Jenderal Pajak.

Direktorat Jenderal Pajak. 2015. Surat Edaran Direktur Jenderal Pajak Nomor SE39/PJ/2015 tentang Pengawasan Wajib Pajak dalam Bentuk Permintaan Penjelasan atas Data dan/atau Keterangan, dan Kunjungan (Visit) kepada Wajib Pajak. Jakarta: Direktorat Jenderal Pajak.

Kementerian Keuangan. 2019. APBN 2019. Jakarta: Sekretariat Negara.

Republik Indonesia. 2009. Undang-undang Republik Indonesia Nomor 16 Tahun 2009 tentang Perubahan Keempat Atas Undang-undang Nomor 6 Tahun 1983 tentang Ketentuan Umum dan Tata Cara Perpajakan.

Republik Indonesia. 2000. Undang-undang Republik Indonesia Nomor 19 Tahun 2000 tentang Perubahan Atas Undang-undang Nomor 19 Tahun 1997 tentang Penagihan Pajak dengan Surat Paksa. 